\title{
Effect of acetaminophen (paracetamol) on human osteosarcoma cell line MG63
}

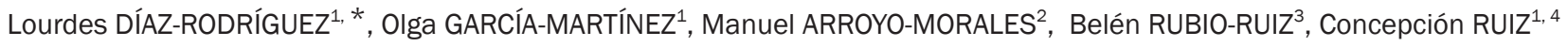 \\ ${ }^{1}$ Department of Nursing, Faculty of Health Sciences, University of Granada, 18071 Granada, Spain; ${ }^{2}$ Department of Physiotherapy, \\ Faculty of Health Sciences, University of Granada, 18071 Granada, Spain; ${ }^{3}$ Department of Pharmaceutical Chemistry and Organic \\ Chemistry, Faculty of Pharmacy, University of Granada, 18071 Granada, Spain; ${ }^{4}$ Institute of Neuroscience, Faculty of Medicine, Univer- \\ sity of Granada, 18071 Granada, Spain
}

\begin{abstract}
Aim: To examine the effects of acetaminophen (paracetamol), a nonsteroidal anti-inflammatory drug (NSAID), on different cellular and functional parameters of the human osteosarcoma cell line MG63.

Methods: Flow cytometry was used to study proliferation, antigenic profile, and phagocytic activity, and radioimmunoassay was used to determine osteocalcin synthesis as a cell differentiation marker.

Results: Short-term treatment with therapeutic doses of paracetamol( 5 or $25 \mu \mathrm{mol} / \mathrm{L})$ reduced cell proliferation, osteocalcin synthesis, and phagocyte activity, and increased the expression of antigens involved in antigen presentation to T lymphocytes (CD80, CD86, HLADR).

Conclusion: These findings suggest that paracetamol activates the osteoblast, inducing its immunogenic action to the detriment of its bone formation capacity.
\end{abstract}

Keywords: nonsteroidal anti-inflammatory drugs; acetaminophen; osteosarcoma; MG63

Acta Pharmacologica Sinica (2010) 31: 1495-1499; doi: 10.1038/aps.2010.129

\section{Introduction}

Nonsteroidal anti-inflammatory drugs (NSAIDs) are frequently administered after orthopedic surgery for their antiinflammatory, antipyretic, and analgesic capabilities. Their anti-inflammatory effects result from inhibition of prostaglandin (PG) biosynthesis via action on the cyclooxygenase (COX) involved in catabolism of arachidonic acid, which is present in the phospholipid membrane of cells ${ }^{[1-3]}$.

Acetaminophen (paracetamol) is a widely used NSAID for its analgesic and mild anti-inflammatory actions. Although its pharmacologic action has not been attributed to a significant inhibition of peripheral prostanoids, Hinz et al ${ }^{[4]}$ recently demonstrated that acetaminophen inhibited COX-2 to a degree comparable to the effect of other NSAIDs and selective COX-2 inhibitors.

Several studies demonstrated that indomethacin, ketorolac, diclofenac, and celecoxib, among other NSAIDs, suppress bone growth, remodeling, and repair ${ }^{[5-7]}$, although the mechanism of this action is not fully understood. Research has

\footnotetext{
* To whom correspondence should be addressed.

E-mail cldiaz@ugr.es

Received 2010-01-14 Accepted 2010-06-03
}

focused on the activity of osteoblasts, which play an important role in bone formation and regeneration and are reported to have both bone-forming and immunological functions. We draw attention to: the high expression of antigens involved in antigen presentation in bone tissue sections ${ }^{[8]}$, primary cultures, and human osteosarcoma cell line MG-63 ${ }^{[9-12]}$; the elevated expression of various cytokines ${ }^{[13,14]}$; and their phagocytic capacity of osteoblasts against targets of different size and nature ${ }^{[11,12]}$.

Unlike other NSAIDs, the effect of paracetamol on bone tissue has not yet been investigated, despite its very wide therapeutic utilization, especially as an analgesic. We therefore designed a study to explore its effects on molecular, cellular, and functional parameters of osteoblasts treated with a dose of 5 and/or $25 \mu \mathrm{mol} / \mathrm{L}$, which are within the therapeutic range $^{[15]}$. We selected the human osteosarcoma cell line MG63, which is frequently used as model to study the effect of pharmaceuticals on these osteoblasts ${ }^{[12,16,17]}$.

\section{Materials and methods}

Cell line

We used the human osteosarcoma cell line MG63, purchased from American Type Cultures Collection (ATCC, Manassas, VA). 


\section{Drugs}

Paracetamol (Sigma Chem Comp, St Louis, MO, USA).

\section{Cell Culture}

The human osteosarcoma cell line MG63 was maintained in Dulbecco's modified Eagle medium (DMEM; Invitrogen Gibco Cell Culture Products, Carlsbad, CA) with $100 \mathrm{IU} / \mathrm{mL}$ penicillin (Lab Roger SA, Barcelona, Spain), $50 \mu \mathrm{g} / \mathrm{mL}$ gentamicin (Braum Medical SA, Jaen, Spain), $2.5 \mu \mathrm{g} / \mathrm{mL}$ amphotericin B (Sigma, St Louis, MO, USA), 1\% glutamine (Sigma, St Louis, MO, USA), 2\% HEPES (Sigma, St Louis, MO, USA), and supplemented with 10\% fetal bovine serum (FBS) (Gibco, Paisley, UK). Cultures were kept at $37^{\circ} \mathrm{C}$ in a humidified atmosphere of $95 \%$ air and $5 \% \mathrm{CO}_{2}$. Cells were detached from the culture flask with a solution of $0.05 \%$ Trypsin (Sigma, St Louis, MO, USA) and $0.02 \%$ ethylenediaminetetraacetic acid (EDTA) (Sigma, St Louis, MO, USA) and then washed and suspended in complete culture medium with $10 \%$ FBS.

\section{Cell proliferation assay}

Osteoblasts were seeded at $1 \times 10^{4}$ cells $/ \mathrm{mL}$ per well into a 24-well plate (Falcon, Becton Dickinson Labware, NJ, USA) without FBS and cultured for $24 \mathrm{~h}$ with the different concentrations of paracetamol $(5-25 \mu \mathrm{mol} / \mathrm{L})$ at $37{ }^{\circ} \mathrm{C}$. Cells were detached, washed, and suspended in PBS and then immediately analyzed in a flow cytometer Ortho Absolute (Ortho Diagnostic System, Raritan, USA). All experiments included an internal control, ie, cells incubated under the same conditions but without paracetamol.

\section{Antigenic phenotype by flow cytometry}

Cultured osteoblastic cells were previously treated with 25 $\mu \mathrm{mol} / \mathrm{L}$ of paracetamol in FBS-free medium for $24 \mathrm{~h}$ at $37^{\circ} \mathrm{C}$. They were then detached from the culture flask by treatment with $0.4 \%$ EDTA solution, washed, and suspended in phosphate-buffered saline (PBS) at $2 \times 10^{4}$ cells $/ \mathrm{mL}$. Cells were labeled by direct staining with the MABs shown in Table 1. Aliquots of $100 \mu \mathrm{L}$ of the cell suspension were incubated with

Table 1. Monoclonal antibodies (MABs) used to study antigenic phenotype on cultured human osteoblastic-like cells, with their specificity, the fluorochrome used to label the antibody, and the supplier. FITC: Fluorescein-isothiocyanate. PE: Phycoerythrin.

\begin{tabular}{llll}
\hline \multicolumn{1}{c}{ MABs } & CD/specificity & $\begin{array}{c}\text { Fluoro- } \\
\text { chrome }\end{array}$ & Supplier \\
\hline Control PE & - & PE & Caltag (Burlingame, CA) \\
Control FITC & - & FITC & Caltag (Burlingame, CA) \\
OKM13 & CD13 & FITC & Caltag (Burlingame, CA) \\
CD21 & CD21 & PE & Caltag (Burlingame, CA) \\
CD44 & CD44 & FITC & Caltag (Burlingame, CA) \\
IOL1b & CD54 & FITC & Caltag (Burlingame, CA) \\
CD80 & CD80 & FITC & Caltag (Burlingame, CA) \\
CD86 & CD86 & FITC & Caltag (Burlingame, CA) \\
OKDR & HLA-DR & FITC & Caltag (Burlingame, CA) \\
\hline
\end{tabular}

$10 \mu \mathrm{L}$ of the appropriate MAB for $30 \mathrm{~min}$ at $4{ }^{\circ} \mathrm{C}$ in the dark. Cells were washed, suspended in $1 \mathrm{~mL}$ PBS, and immediately analyzed in a flow cytometer with argon laser (Facs Vantage Becton Dickinson, Palo Alto, California, USA) at a wavelength of $488 \mathrm{~nm}$ to determine fluorescent cell percentage. As controls, untreated cells were stained with the MABs. The percentage of antibody-positive cells was calculated from counts of 2000-3000 cells. At least four experiments were run for each antigen.

\section{Osteocalcin synthesis}

Osteocalcin was quantified in culture supernatants by using the N-tact ${ }^{\circledR}$ osteo SP kit for IRMA osteocalcin (Diasorin-Stillwater, Minesota, USA). For this purpose, cells were cultured for $24 \mathrm{~h}$ in FBS-free medium in the presence of $25 \mu \mathrm{mol} / \mathrm{L}$ of paracetamol, and the supernatant was obtained by centrifuge at $1600 \mathrm{r} / \mathrm{min}$. Samples were analyzed in duplicate using the $\mathrm{N}$-tact ${ }^{\circledR}$ osteo SP kit. Results were expressed in picograms of osteocalcin $/ \mathrm{mL} \times 10^{4}$ cells. Supernatants of cultures kept under the same conditions but without treatment served as controls.

\section{Phagocytic activity of MG63 lines}

Phagocytic activity was studied by flow cytometry. Cultured human MG63 osteosarcoma cells treated with $25 \mu \mathrm{mol} / \mathrm{L}$ of paracetamol and untreated control cells were cultured without FBS and detached from the culture flask by treatment with $0.04 \%$ EDTA solution, washed, and then suspended in complete culture medium with $10 \%$ FBS at $2 \times 10^{4}$ cells $/ \mathrm{mL}$. Cells were labeled by direct staining with labeled latex beads. One hundred microliters of cell suspension were incubated with $200 \mu \mathrm{L}$ carboxylated FICT-labeled latex beads of $2 \mu \mathrm{m}$ diameter (Sigma Adrich, St Louis, USA) for $30 \mathrm{~min}$ at $37^{\circ} \mathrm{C}$ in darkness. Cells were washed, suspended in $1 \mathrm{~mL}$ PBS, and immediately analyzed in a flow cytometer (Fasc Vantage Becton Dickinson, Palo Alto, California, USA). Results were expressed as percentage of cells positive for phagocytosis and mean channel fluorescence, which correlates with the number of particles phagocytosed.

\section{Statistical analysis}

Statistical comparisons were determined by using the Student's $t$-test, and $P<0.05$ was considered significant.

\section{Results}

Effect of paracetamol treatment on proliferation of MG63 cell line

The effects of 24-h treatment with each paracetamol dose (5 or $25 \mu \mathrm{mol} / \mathrm{L})$ on cell growth of the MG63 cell line were determined by cell count, finding a statistically significant reduction in MG63 cell proliferation with both doses $(P<0.01$ for both dose). After $24 \mathrm{~h}$ culture of $10^{4}$ cells in each case, the mean viable cell count was $39.53 \times 10^{4}$ cells $/ \mathrm{mL}$ in the control cultures versus $28.37 \times 10^{4}$ cells $/ \mathrm{mL}$ in the $5 \mu \mathrm{mol} / \mathrm{L}$-treated cultures and $26.18 \times 10^{4}$ cells $/ \mathrm{mL}$ in the $25 \mu \mathrm{mol} / \mathrm{L}$-treated cultures (Figure $1)$. Because a greater effect on proliferation was observed with 


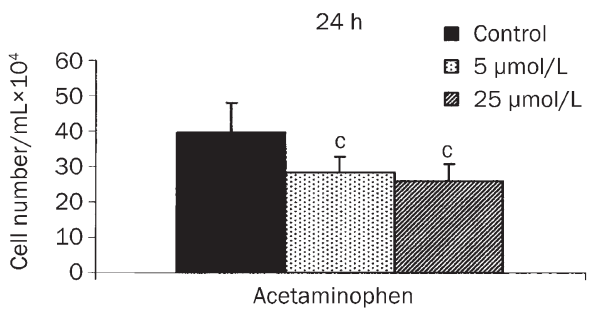

Figure 1. Effects of acetaminophen on osteoblast proliferation in MG63 cell line after $24 \mathrm{~h}$ of incubation at 5 or $25 \mu \mathrm{mol} / \mathrm{L}$. Data are shown in the mean \pm SEM. Data from acetaminophen-treated and control cultures were compared using the Student's $t$-test. ${ }^{\circ} P<0.01$.

the higher dose $(25 \mu \mathrm{mol} / \mathrm{L})$, it was selected as the dose to be used in analyses of the effects on the remaining study parameters.

Effect of paracetamol treatment on antigenic phenotype of MG63 cell line

Using flow cytometry, we studied the effect of treatment with $25 \mu \mathrm{mol} / \mathrm{L}$ paracetamol on the expression of different surface markers of the MG63 cell line in order to determine its antigenic profile. Results obtained showed that treatment with $25 \mu \mathrm{mol} / \mathrm{L}$ of paracetamol for $24 \mathrm{~h}$ significantly increased the expression of CD21, CD44, CD80, CD86, and HLA-DR antigens $(P<0.01$ for CD21, $P<0.05$ for CD44 and $P<0.01$ for CD80, CD86, and HLA-DR), but had no effect on CD13 and CD54 antigens (Figure 2, Table 2).

Table 2. Expression of different antigens in MG63 cell line after $24 \mathrm{~h}$ of incubation with $25 \mu \mathrm{mol} / \mathrm{L}$ of acetaminophen by flow cytometry. Data are shown in the mean \pm SEM. ${ }^{\mathrm{b}} P<0.05,{ }^{\mathrm{C}} P<0.01$ vs control.

\begin{tabular}{|c|c|c|c|c|}
\hline \multirow{2}{*}{$\begin{array}{l}\text { Treatment } \\
\text { Antigens }\end{array}$} & \multicolumn{2}{|c|}{ Expression (\%) } & \multicolumn{2}{|c|}{ Fluorescency intensity } \\
\hline & Control & Acetetaminophen & Control & Acetaminophen \\
\hline CD13 & $90.24 \pm 3.52$ & $93.29 \pm 2.60$ & $131.66 \pm 3.78$ & $89.15 \pm 1.58^{c}$ \\
\hline $\mathrm{CD} 21$ & $79.91 \pm 2.38$ & $93.34 \pm 2.10^{c}$ & $34.22 \pm 3.98$ & $65.83 \pm 2.42^{c}$ \\
\hline CD44 & $84.61 \pm 0.51$ & $88.63 \pm 1.90^{b}$ & $41.79 \pm 1.60$ & $38.92 \pm 1.74$ \\
\hline CD54 & $75.01 \pm 3.84$ & $77.71 \pm 2.59$ & $63.67 \pm 3.28$ & $47.32 \pm 3.01^{c}$ \\
\hline $\mathrm{CD} 80$ & $16.17 \pm 2.47$ & $62.92 \pm 1.55^{\mathrm{c}}$ & $24.05 \pm 4.06$ & $22.68 \pm 2.62$ \\
\hline CD86 & $6.62 \pm 1.55$ & $29.81 \pm 3.46^{c}$ & $27.14 \pm 1.70$ & $23.63 \pm 1.80$ \\
\hline HLA-DR & $5.93 \pm 1.60$ & $11.75 \pm 3.18^{c}$ & $31.10 \pm 3.53$ & $18.68 \pm 1.35^{c}$ \\
\hline
\end{tabular}

Effect of paracetamol treatment on osteocalcin synthesis in MG63 cell line

The effect of paracetamol on cell differentiation/maturation was studied by using osteocalcin synthesis as a marker. According to the osteocalcin levels in culture supernatants, treatment with $25 \mu \mathrm{mol} / \mathrm{L}$ paracetamol for $24 \mathrm{~h}$ significantly decreased osteocalcin synthesis $(P<0.05)$, finding mean values of $0.50 \mathrm{pg} / \mathrm{mL} \times 10^{4}$ cells in the treated cultures versus 2.60 $\mathrm{pg} / \mathrm{mL} \times 10^{4}$ cells in the untreated (control) cultures (Figure 3).
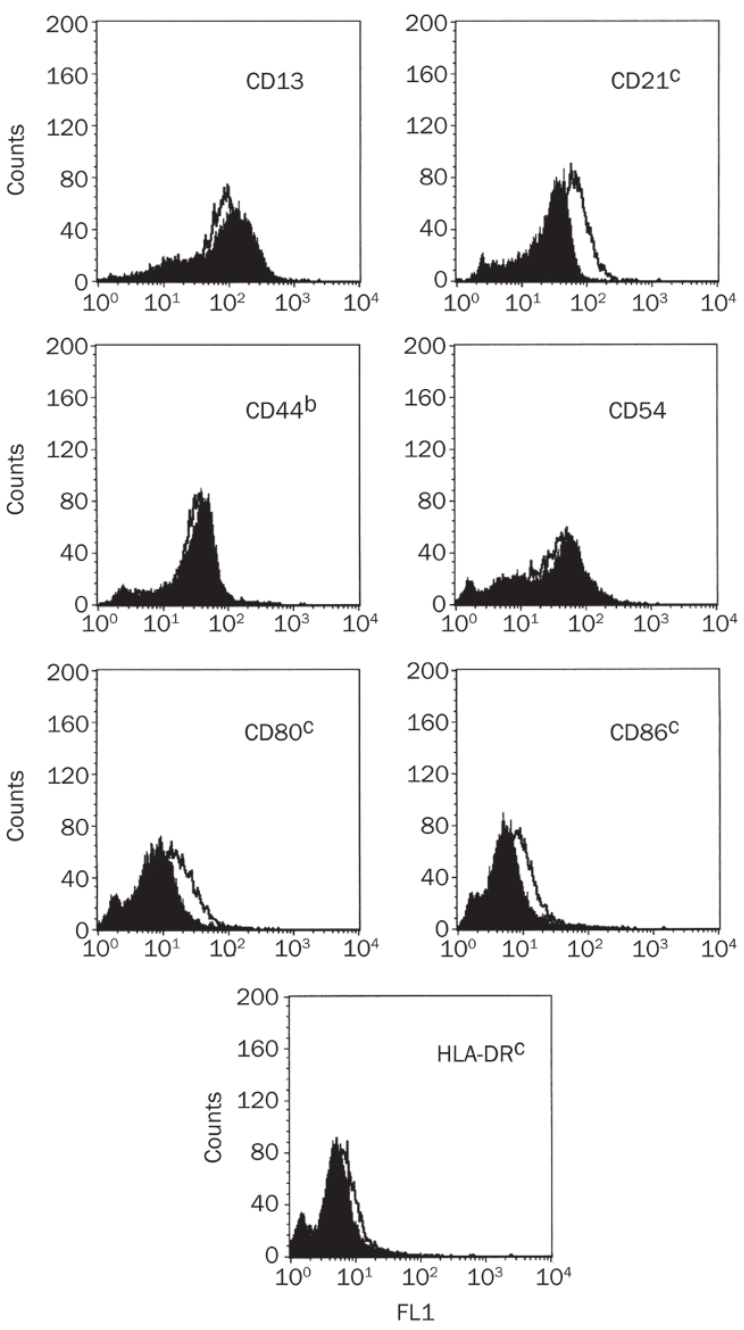

Figure 2. Flow cytometry analysis of MG63 cell line after $24 \mathrm{~h}$ of incubation. Cultures were treated with $25 \mu \mathrm{mol} / \mathrm{L}$ of acetaminophen (white), and the non-drug treated cultures were the control (black). ${ }^{\mathrm{b}} P<0.05,{ }^{\mathrm{c}} P<0.01$.

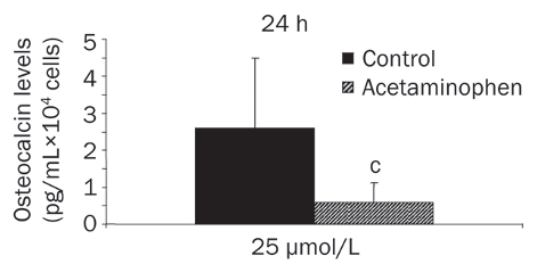

Figure 3. Effects of acetaminophen on quantitative determination of osteocalcin in MG63 cell line after $24 \mathrm{~h}$ of incubation with $25 \mu \mathrm{mol} / \mathrm{L}$ of acetaminophen. Data are shown as mean \pm SEM. ${ }^{c} P<0.01$.

\section{Effect of paracetamol treatment on phagocytic activity of MG63} line

Table 3 and Figure 4 show the effects of paracetamol on the phagocytic capacity of the MG63 line (analyzed by flow cytometry) which was significantly decreased after a $24-\mathrm{h}$ 
Table 3. Effects of acetaminophen on phagocytic capacity in MG-63 cell line after $24 \mathrm{~h}$ treatment at $25 \mu \mathrm{mol} / \mathrm{L}$. Data are expressed as mean \pm SEM. Comparisons of data between treatment and control culture were evaluated by Student's $t$-test. Data are shown in the mean \pm SEM. ${ }^{\mathrm{c}} P<0.01$.

\begin{tabular}{lcc}
\hline Treatment & Expression (\%) & Fluorescency intensity \\
\hline Control & $97.21 \pm 1.33$ & $127 \pm 4.25$ \\
Acetaminophen & $51.25 \pm 7.26^{\circ}$ & $106.66 \pm 7.63$ \\
\hline
\end{tabular}

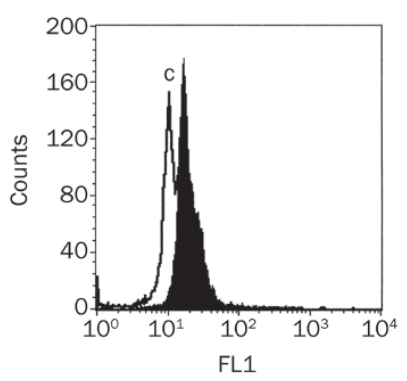

Figure 4. Fluorescence histogram of the expression of phagocytic activity of MG63 cell line after treatment with acetaminophen studied by flow cytometry. Cultures were treated with $25 \mu \mathrm{mol} / \mathrm{L}$ of acetaminophen (white), and the non-drug treated cultures were the control (black). Experiments were repeated at least three times. Data are shown in the mean \pm SEM. ${ }^{c} P<0.01$.

treatment with $25 \mu \mathrm{mol} / \mathrm{L}$ paracetamol $(P<0.01)$ (Table 3, Figure 4).

\section{Discussion}

This study showed that 5 and $25 \mu \mathrm{mol} / \mathrm{L}$ paracetamol, within the therapeutic dose range ${ }^{[17]}$, may exert a short-term inhibitory effect on the proliferative capacity of MG63 cell line. Bone tissue can regenerate under physiological conditions, but alterations during early wound-healing may delay bone regeneration or, in implants, osseointegration. These results are in agreement with the effects of other NSAIDs on osteoblast growth reported in in vivo and in vitro studies ${ }^{[6,7,19,20]}$. For some time, this adverse effect on bone tissue has largely been attributed to the role of $\mathrm{PGE}_{2}$ in bone formation ${ }^{[5,6,7]}$. However, Chang et al ${ }^{[21]}$ showed that NSAIDs significantly arrest the cell cycle in $\mathrm{G}_{0} / \mathrm{G}_{1}$ and induce cytotoxicity and osteoblast cell death; they reported that the cytotoxic and apoptotic effects of NSAIDs on osteoblasts might not be prostaglandinrelated. Hence, it has been proposed that the induction by NSAIDs of cell cycle arrest and cell death in osteoblasts may be an important mechanism contributing to their suppressive effect on bone formation. Studies on cell lines from other tissues showed that NSAIDs produce cell cycle arrest and induce apoptosis ${ }^{[22-25]}$. However, the underlying mechanism is thought to be complex and various factors have been implicated, including PG synthesis inhibition, apoptosis induction by different pathways, cell cycle alteration or arrest, and the dose of the NSAID in question ${ }^{[26-28]}$.

The present study showed that paracetamol affects osteocalcin synthesis, antigenic profile, and phagocytic activity. Type I collagen, alkaline phosphatase, and osteocalcin can all be used as markers of osteoblast maturation. Osteocalcin was selected for this study because it is the most abundant non-collagenous protein of bone, and its synthesis increases during final stages of osteoblast differentiation and maturation ${ }^{[29]}$. Osteocalcin synthesis was lower during cell differentiation, suggesting that this pharmaceutical not only decreases proliferative capacity but may also arrest osteoblast differentiation.

A similar effect on the antigenic profile of paracetamol treatment was previously reported in osteoblasts in inflammatory situations in vitro and in vivo ${ }^{[13,30]}$. This effect is explained as the response of osteoblasts to proinflammatory situations, in which there appears to be an activation of their immune function to the detriment of their bone forming function and their differentiation/maturation. This is supported by our findings of no change in the percentage expression of CD54 molecule and a decrease in osteocalcin synthesis.

Osteoblasts and dendritic cells have characteristics in common, including cytokine synthesis, phagocytic capacity, antigenic presentation to $\mathrm{T}$ lymphocytes, and the expression of certain antigens. It has been reported that dendritic cells increase expression of class II and costimulatory molecules in some situations, eg, infections, finding that the expression of chemokine receptors and adhesion molecules was modified in the presence of microbial products ${ }^{[3]}$. This effect is usually found in parallel with a decrease in the phagocytic capacity of the cell, interpreted as a process of cell activation aimed at responding to specific situations, with an increase in antigen presentation to $\mathrm{T}$ lymphocytes and a reduction in phagocytic capacity. Paracetamol may act in a similar manner, activating the osteoblast and producing an increase in the expression of certain membrane antigens and a decrease in its phagocytic capacity. These results reflect a common situation observed in many cell types, which transform their function under treatment, as reported for macrophages, decidual cells and fibroblasts $^{[32-35]}$.

These experimental data indicate that paracetamol may have an effect on bone tissue, modifying various physiological parameters of osteoblasts. It should be taken account that the MG63 cell line was used as osteoblast model, with the limitations that this implies, although it is one of the most widely used lines in the study of the effect of drugs on osteoblasts $^{[12,16,17]}$. Further research is warranted to evaluate the use of this drug in patients requiring bone regeneration.

\section{Acknowledgements}

This study was supported by research group BIO277 (Junta de Andalucía) and by the Department of Nursing of the Health Sciences School of the University of Granada.

\section{Author contribution}

Lourdes DÍAZ-RODRÍGUEZ: performed research; analyzed data and wrote the paper; Olga GARCÍA-MARTÍNEZ: per- 
formed research; Manuel ARROYO-MORALES: collaboration in development of performed research; Belén RUBIO-RUIZ: collaboration in development of performed research; Concepción RUIZ: designed research, analyzed data, and wrote the paper.

\section{References}

1 Ferreira SH, Nakamura M, Castro M. The hyperalgesic effects of prostaciclin and prostaglandin E2. Prostaglandins 1978; 16: 31-7.

2 Smith WL, Dewitt DL, Garavito RM. Cyclooxygenases: structural, cellular, and molecular biology. Ann Rev Biochem 2000; 69: 145-82.

3 Esplugues JV, Barrachina MD. Mediadores celulares II. Eicosanoides. Óxido Nítrico y factor activador de plaquetas. In: Flórez J, Armijo JA, Mediavilla A, editors. Farmacología Humana. Barcelona: Masson; 2004. p47-362.

4 Hinz B, Cheremina O, Brunek. Acetaminophen (paracetamol) is a selective cyclooxigenase-2 inhibitor in man. FASEB J 2008; 22: 383-90.

5 Davies M, Anderson K. Clinical pharmacokinetic of diclofenac: therapeutic insights and pitfalls. Clin Pharmacokinet 1997; 33: 184213.

6 Ho ML, Chang JK, Chuang LY, Hsu HK, Wang GJ. Effects of nonsteroidal anti-inflammatory drugs and prostaglandins on osteoblastic functions. Biochem Pharmacol 1999; 58: 983-90.

7 Krischak GD, Augat P, Sorg T, Blakytny R, Kinzl L, Claes L and Beck A. Effects of diclofenac on periosteal callus maturation in osteotomy healing in animal model. Arch Orthop Trauma Surg 2007; 127: 3-9.

8 Garcia-Martinez 0, Reyes-Botella C, Aguilera-Castillo 0, VallecilloCapilla MF, Ruiz C. Antigenic profile of osteoblasts present in human bone tissue sections. Bioscience Rep 2006; 26: 39-43.

9 Reyes-Botella C, Montes MJ, Vallecillo-Capilla MF, Olivares EG, Ruiz C. Expression of molecules involved in antigen presentation and $T$ cell activation (HLA-DR, CD80, CD86, CD44, and CD54) by cultured human osteoblasts. J Periodontol 2000; 71: 614-7.

10 Reyes-Botella C, Montes MJ, Vallecillo-Capilla MF, Olivares EG, Ruiz C. Antigenic phenotype of cultured human osteoblast-like cells. Cell Physiol Biochem 2002; 12; 359-64.

11 Ruiz C, Pérez E, Vallecillo-Capilla MF, Reyes-Botella C. Phagocytosis and allogeneic $T$ cell stimulation by cultured human osteoblastic-like cells. Cell Physiol Biochem 2003; 13: 309-14.

12 Díaz-Rodríguez L, García-Martínez O, Arroyo-Morales M, ReyesBotella C, Ruiz C. Antigenic phenotype and phagocytic capacity of MG63 osteosarcoma line. Ann N Y Acad Sci 2009; 1173 (Suppl 1): E46-E54.

13 Pérez E, Garcia-Martinez O, Arroyo-Morales M, Reyes-Botella C, Ruiz C. Modulation of antigenic phenotype in cultured human osteoblast-like cells by FGFb, TGFbeta1, PDGF-BB, IL-2, IL-1beta, LPS and IFNgamma. Bioscience Rep 2006; 26: 281-9.

14 Ruiz C, Pérez E, García-Martínez O, Díaz L, Arroyo M, Reyes-Botella C. Expression of cytokins IL-4, IL-12, IL-15, IL-18 y IFN and modulation by different growth factors in cultured human osteoblast-like cells. J Bone Miner Metab 2007; 25: 286-92.

15 Thummel KE, Slattery JT, Ro H, Chien JY, Nelson SD, Lown KE, Watkins PB. Ethanol and production of the hepatotoxic metabolite of acetaminophen in healthy adults. Clin Pharmacol Ther 2000; 67: 591-9.

16 Prouillet C, Mazičre JC, Mazičre C, Wattel A, Brazier M, Kamel S. Stimulatory effect of naturally occurring flavonols quercetin and kaempferol on alkaline phosphatase activity in MG-63 human osteoblasts through ERK and estrogen receptor pathway. Biochem Pharmacol 2004; 67: 1307-13.
17 Nayab SN, Jones FH, Olsen I. Effects of calcium ion implantation on human bone cell interaction with titanium. Biomaterial 2005; 26 : 4717-27.

18 Thummel KE, Slattery JT, Ro H, Chien JY, Nelson SD, Lown KE, et al. Ethanol and production of the hepatotoxic metabolite of acetaminophen in healthy adults. Clin Pharmacol Ther 2000; 67: 591-9.

19 Evans CE, Butcher C. The influence on human osteoblasts in vitro of non-steroidal anti-inflammatory drugs which act on different cyclooxygenase enzymes. J Bone Joint Surg Br 2004; 86: 444-9.

20 Kaspar D, Hedrich CM, Schmidt C, Liedert A, Claes LE, Ignatus AA. Diclofenac inhibits proliferation and matrix formation of osteoblasts cells. Unfallchirurg 2005; 108: 20-4.

21 Chang JK, Wang GJ, Tsai ST, Ho ML. Nonsteroidal anti-inflammatory drug effects on osteoblastic cell cycle, cytotoxicity, and cell death. Connect Tissue Res 2005; 46: 200-10.

22 Piazza GA, Rahm AK, Finn TS, Fryer BH, Li H, Stoumen AL, Pamukcu $\mathrm{R}$, Ahnen DJ. Apoptosis primarily accounts for the growth-inhibitory properties of sulindac metabolites and involves a mechanism that is independent of cyclooxygenase inhibition, cell cycle arrest, and p53 induction. Cancer Res 1997; 57: 2452-9.

23 Agarwal B, Swaroop P, Protiva P, Raj SV, Shirin H, Holt PR. COX-2 is needed but not sufficient for apoptosis induced by Cox-2 selective inhibitors in colon cancer cells. Apoptosis 2003; 8: 649-54.

24 Chang JK, Li CJ, Wu SC, Yeh CH, Chen CH, Fu YC, et al. Effects of antiinflammatory drugs on proliferation, cytotoxicity and osteogenesis in bone marrow mesenchymal stem cells. Biochem Pharmacol 2007; 74: 1371-82.

25 Chang JK, Li CJ, Liao HJ, Wang CK, Wang GJ, Ho ML. Anti-inflammatory drugs suppress proliferation and induce apoptosis through altering expressions of cell cycle regulators and pro-apoptotic factors in cultured human osteoblasts. Toxicology 2009; 258: 148-56.

26 Zhang L, Yu J, Park BH, Kinzler KW, Vogelstein B. Role of BAX in the apoptotic response to anticancer agents. Science 2000; 290: 98992.

27 Maier TJ, Schilling K, Schmidt R, Geisslinger G, Grosch S. Cyclooxygenase-2 (COX-2)-dependent and -independent anticarcinogenic effects of celecoxib in human colon carcinoma cells. Biochem Pharmacol 2004; 67: 1469-78.

28 Lee KH, Choi EM. Biochanin A stimulates osteoblastic differentiation and inhibits hydrogen peroxide-induced production of inflammatory mediators in MC3T3-E1 cells. Biol Pharm Bull 2005; 28: 1948-53.

29 Aubin JE, Liu F, Malaval L, Gupta AK. Osteoblast and chondroblast differentiation. Bone 1995; 17(Suppl 2): S77-S83.

30 Stanley KT, Vandort C, Motyl C, Endres J, Fox DA. Immunocompetent properties of human osteoblasts: interactions with T lymphocytes. J Bone Miner Res 2006; 21: 29-36.

31 Andreae S, Piras F, Burdin N, Triebel F. Maturation and activation of dendritic cells induced by lymphocyte activation gene-3 (CD223). J Immunol 2002; 168: 3874-80.

32 Geissman F, Manz MG, Jung S, Sieweke MH, Merad M, Ley K. Development of monocytes, macrophages, and dendritic cells. Science 2010; 327: 656-61.

33 Barnett JB, Brundage KM. Evaluating macrophages in immunotoxicity testing. Methods Mol Biol 2010; 598: 75-94.

34 Ruiz C, Montes MJ, Abadía-Molina AC, Olivares EG. Phagocytosis by fresh and cultured human decidual stromal cells: opposite effects of interleukin-1 alpha and progesterone. J Reprod Immunol 1997; 33: 15-26.

35 Pretzel D, Pohlers D, Weinert S, Kinne RW. In vitro model for the analysis of synovial fibroblast-mediated degradation of intact cartilage. Arthritis Res Ther 2009; 11: R25. 